\title{
BIMBINGAN KELOMPOK DALAM MENGATASI STRES
}

\author{
Armila \\ Institut Agama Islam Negeri Metro Lampung \\ Armila24081986@gmail.com
}

\begin{abstract}
Group guidance is one of the guidance techniques that seek to help individuals to achieve optimal development in accordance with the abilities of talents, interests, and values that are adopted and implemented in group situations. Group guidance is intended to prevent problems arising in individuals and develop individual potential. The group guidance service has three functions First, the informative function, Second, the development function. Both of these functions for example, group guidance is carried out through the activity of the Home Room, while the third, preventive and creative functions, are used for the treatment of psychological problems such as psychodrama, or sociodrama for the treatment of problems or social conflicts. In this paper the group guidance service is one of the media oriented towards efforts to help individuals develop themselves in order to be more independent, be able to socialize well, be able to practice speaking, responding, giving other people's opinions, being able to work together, caring with others, fostering normative attitudes and behavior as well as other aspects, tolerance and in turn individuals can develop their own potential and can improve their personal communication behavior, and most importantly, learn to take the right decisions for themselves in order to achieve more future goals good.
\end{abstract}

\section{Keywoard: Guidance, Group, Stress}




\section{A. Pendahuluan}

Stres dalam kehidupan merupakan sesuatu bagian dari fenomena kehidupan manusia. Stres dapat di alami oleh semua individu di masyarakat. Selain itu, gejala stres dapat di alami oleh siapa saja yang mana fenomena stres sendiri dapat muncu karena di akibatkan oleh beberapa faktor yang dapat membuat seseorang mengalami stres. Stres merupakan bagian dari kehidupan manusia dan dapat dialami oleh siapa saja, Stres dapat ditimbulkan oleh berbagai sumber. seperti berasal dari lingkungan keluarga, Sumber stres pada mereka pun berasal dari lingkungan sekolah, dan lingkungan masyarakat, atau bahkan bersumber dari dirinya sendiri. Sumber stres utama pada masa ini adalah konflik atau pertentangan antara dominasi, peraturan atau tuntutan orang tua dengan remaja untuk bebas, atau independen dari peraturan tersebut". ${ }^{1}$

Apabila anak puber tidak diberitahu atau secara psikologis tidak dipersiapkan tentang perubahan fisik dan psikologis yang terjadi pada masa puber, perubahan itu dapat merupakan pengalaman yang traumatis. ${ }^{2}$ Pernyataan tersebut mengandung makna bahwa jika remaja tidak pernah mendapatkan penjelasan mengenai perubahan yang terjadi pada dirinya tersebut merupakan sesuatu yang wajar, maka ia akan mengalami ketakutan, kecemasan, kegoncangan, bahkan stres.

Dalam bimbingan konseling terdapat beberapa teknik yang dapat digunakan untuk membantu individu mengatasi permasalahan yang dialami. Teknik-teknik tersebut antara lain, bimbingan kelompok, konseling individual, dan konseling kelompok $^{3}$. Kegiatan bimbingan sebagai upaya membantu seseorang untuk mengelola stres yang dialaminya mencakup kegiatan pemberian informasi mengenai berbagai hal yang berhubungan dengan stres remaja. Maka teknik bimbingan

1 Syamsu Yusuf. Seri Kegiatan Pendukung Konseling, Layanan Bimbingan Kelompok/ Konseling Kelompok, (Padang: BK FIP UNP, 2004), h. 95

2 Elizabeth B. Hurlock. Psikologi Perkembangan Suatu Pendekatan Kehidupan, (Erlangga, 1997), h, 198

3 Prayitno. Seri Bimbingan dan Konseling di sekolah (Dasar dan Profil), (Jakarta : Ghalia Indonesia, 1995), h 
kelompok merupakan teknik yang dapat digunakan untuk membantu siswa mengelola stres.

Hal ini sesuai dengan pendapat Juntika bahwa "Isi kegiatan bimbingan kelompok terdiri atas penyampaian informasi yang berkenaan dengan masalah pendidikan, pekerjaan, pribadi dan masalah sosial yang tidak disajikan dalam bentuk pelajaran ". 4

Suasana kelompok yang kondusif dapat dibangun oleh kerjasama yang baik antara konselor dengan siswa, maka hal tersebut dapat membantu kesulitan siswa dalam mengungkapkan masalah yang dihadapinya. mind mapping yang diintegrasikan ke dalam proses bimbingan kelompok tersebut untuk memberikan bantuan pada siswa.

Bimbingan mengindikasikan bahwa stres memang dapat berdampak serius membutuhkan pertolongan dan bantuan dari orang disekitarnya yang tentunya peduli dengan masalah stres yang sedang dihadapinya. Bantuan tersebut dapat berupa dukungan sosial dari orang tua, teman, atau orang-orang terdekatnya.Sama halnya pada orang dewasa, stres bisa berefek negatif pada tubuh remaja. Hanya saja perbedaannya ada pada sumbernya dan bagaimana mereka merespon penyakit tersebut. Reaksi tersebut ditentukan oleh suasana dan kondisi kehidupan yang tengah mereka alami.

\section{B. Pembahasan}

\section{Bimbingan Kelompok}

Bimbingan kelompok merupakan salah satu teknik bimbingan yang berusaha membantu individu agar dapat mencapai perkembangan secara optimal sesuai dengan kemampuan bakat, minat, serta nilai-nilai yang dianutnya dan dilaksanakan dalam situasi kelompok.Bimbingan kelompok ditujukan untuk mencegah timbulnya masalah pada individu dan mengembangkan potensi individu. ${ }^{5}$

4 Juntika. Dasar-dasar dan Teknik Evaluasi Pendidikan, (Padang: UNP, 2005), h. 17

5 Tatik Romlah, Teori dan Praktik Bimbingan Kelompok, (Jakarta: Dirjen Dikti, 1989), h. 3 
Layanan bimbingan kelompok dimaksudkan untuk memungkinkan individu secara bersama-sama memperoleh berbagai bahan dari nara sumber (terutama guru BK) yang bermanfaat untuk kehidupan sehari-hari baik sebagai individu maupun sebagai pelajar, anggota keluarga dan masyarakat. ${ }^{6}$

Sedangkan menurut yang dimaksud dengan layanan bimbingan kelompok adalah "Suatu kegiatan yang dilakukan oleh sekelompok orang dengan memanfaatkan dinamika kelompok membahas berbagai hal yang berguna bagi pengembangan pribadi atau pemecahan masalah individu yang menjadi peserta kegiatan kelompok. Artinya, semua peserta dalam kegiatan kelompok saling berinteraksi, bebas mengeluarkan pendapat, menanggapi, memberi saran dan sebagainya, apa yang dibicarakan itu semuanya bermanfaat untuk diri peserta maupun peserta lainnya. ${ }^{7}$

Dari beberapa pengertian bimbingan kelompok yang telah dikemukakan di atas, maka dapat disimpulkan bahwa bimbingan kelompok adalah suatu kegiatan kelompok yang dilakukan oleh sekelompok orang dengan memanfaatkan dinamika kelompok yaitu melalui adanya interaksi,saling mengeluarkan pendapat, memberikan tanggapan, saran, dan sebagainya.

Layanan bimbingan kelompok merupakan salah satu layanan bimbingan dan konseling dimana layanan pemecahan masalah diberikan dalam suasana kelompok dengan memperhatikan dinamika kelompok. menjelaskan bahwa dalam layanan bimbingan kelompok mempunyai ciriciri yaitu: ${ }^{8}$

a. Tujuan yang akan dicapai dalam kegiatan konseling kelompok adalahpengembangan pribadi, pembahasan topik-topik secara luas dan mendalamyang bermanfaat bagi para anggota kelompok.

${ }^{6}$ Dewa Ketut Sukardi. Pengantar Pelaksanaan Program Bimbingan Kelompok diSekolah. (Jakarta: Rineka Cipta, 2003), h. 48

7 Prayitno. Seri Panduan Layanan dan Kegiatan Pendukung Konseling, (Padang: BK FIP UNP, 2012), h. 149

8 Ibid., h. 188 
b. Jumlah anggota kelompok dibatasi sekitar10-15orang.

c. Kondisi dan karakter anggota kelompok relatif homogen.

d. Format kegiatan kelompok kecil dengan lima tahap.

e. Peranan anggota kelompokaktif membahas topik tertentu yang ditugaskan atau dikemukakan dan dipih secara bebas melalui kegiatan, berpartisipasi aktif dalam dinamika interaksi sosial, setiapanggota kelompok menyumbang untuk pemecahan masalah, dan menyerap informasi,saran, alternatif untuk dimanfaatkan dalam interaksi sosialkelompokdengan mengunakan strategi Berfikir Merasa Bersikap Bertindak Bertanggung jawab (BMB3).

f. Suasana interak simultiarah, mendalam dan tuntas dengan melibatkan aspek kognitif, afektif.

g. Sifat pembicaraan umum tetap menjaga kerahasian.

h. Lama dan frekuensi kegiatan berlangsung dan berkembang sesuai dengan tingkat perluasan dan pendalaman pembahasan topik dilakukan secara meraton.

i. Evaluasi dilaksanakan evaluasi isikedalam pembahasan topik, evaluasi dampak pemahaman dan dampak kegiatan terhadap anggota, Evaluasi proses: keterlibatan anggota dalam kegiatan kelompok dengan mengunakan strategi refleksi BMB3.

j. $\quad$ Pelaksananya konselor. ${ }^{9}$

Pendapat lain dari fokus konseling kelompok menyatakan bahwa untuk menuntaskan masalah pendidikan, sosial, dan pribadi yang meliputi proses interpersonal individu tentang kemampuan diri, perasaan dan tingkahlaku yang akan mempengaruhi pengembangan diri.10Jadi melalui layanan bimbingan kelompok diharapkan setiap anggota akan memperoleh pengembangan diri, memperoleh informasi, dan penuntasan masalah yangdialami melalui dinamika kelompok.

${ }^{9}$ Ibid., h. 188.

10 Corey. Theory \& Practice of Group Counseling, (USA: Thomson Brooks, 2008), h. 10 
a. Tujuan Bimbingan Kelompok

Tujuan layanan bimbingan kelompok bahwasanya tujuan bimbingan kelompok terdiri dari tujuan umum dan tujuan khusus. Secara umum bimbingan kelompok bertujuan untuk membantu para individu yang mengalami masalah melalui prosedur kelompok, mengembangkan pribadi masing-masing anggota kelompok melalui berbagai suasana yang muncul dalam kegiatan, baik suasana yang menyenangkan maupun yang menyedihkan.Secara khusus bimbingan kelompok bertujuan untuk:11 Yaitu: Melatih individu untuk berani mengemukakan pendapat di hadapanteman-temannya, Melatih individu dapat bersikap terbuka di dalam kelompok, melatih individu untuk dapat membina keakraban bersama teman-temandalam kelompok khususnya dan teman di luar kelompok pada umumnya, melatih individu untuk dapat mengendalikan diri dalam kegiatan kelompok.

Ada beberapa tujuan bimbingan kelompok seperti dikemukakan oleh Prayitno, adalah sebagai berikut:12 Pertama, Mampu berbicara di depan orang banyak. Kedua, Mampu mengeluarkan pendapat, ide, saran, tanggapan, perasaandan lain sebagainya kepada orang banyak. Ketiga Belajar menghargai pendapat orang lain. Keempat Bertanggungjawab atas pendapat yang dikemukakannya. Kelima Mampu mengendalikan diri dan menahan emosi (gejolak kejiwaan yang bersifat negatif). Keenam Dapat bertenggang rasa. Ketujuh, Menjadi akrab satu sama lainnya. Ketujuh Membahas masalah atau topik-topik umum yang dirasakan atau menjadi kepentingan bersama. ${ }^{13}$

Menurut Bennet tujuan bimbingan kelompok adalah:

(a) Memberikan kesempatankesempatan kepada individu belajar hal-hal penting yang berguna bagi pengarahan

11 Erman Amti, Prayitno. Seri Kegiatan Pendukung Konseling, Layanan Bimbingan Kelompok/ Konseling Kelompok, (Padang: BK FIP UNP, 2004), h. 108.

12 Prayitno. Seri Bimbingan dan Konseling di sekolah, (Dasar dan Profil), (Jakarta : Ghalia Indonesia, 1996), h.

13 Ibid., h. 178 
dirinya yang berkaitan denganmasalah pendidikan, pekerjaan, pribadi dan sosial,

(b) Memberikanlayanan penyembuhan dengan mempelajari berbagaimasalah manusia pada umumnya, menghilangkan ketegangan-ketegangan emosi dan menambah pengertian mengenai dinamika kepribadian,

(c) Dengan mempelajari masalah-masalah umum yang di almi oleh invividu dan dengan menghilangkan hambatan-hambatan emosional melalui kegiatan kelompok maka pemahaman terhadap masalah individu menjadi lebih mudah. ${ }^{14}$

Layanan bimbingan kelompok dimaksudkan untuk memungkinkan individu bersama-sama memperoleh berbagai bahan dari nara sumber (terutama guru BK) yang bermanfaat untuk kehidupan sehari-hari baik sebagai individu maupun sebagai pelajar, anggota keluargadan masyarakat. ${ }^{15}$

Pendapat lain dari Corey menjelaskan : Tujuan kelompok adalah; a) sebagai sarana belajar untuk memahami diri dan orang lain,b) menambah kesadaran dan pengetahuan tentang keunikan individu,c) mengenal butuhan dan masalah yang dialami sesama anggota, d) membelajarkan individu untuk memahami hubungan dengan orang lain,e) membantu anggota untuk menemukan sumber yang dapat dimanfaatkan untuk diri melalui anggota kelompok, f) dapat menambah penerimaan diri, kepercayaan diri, dan respek terhadap orang lain, g) belajar untukmengekpresikan emosi yang sehat melalui anggota kelompok, h)mengembangkan hubungan dan membandingkan diri dengan orang lain,menambah kepercayaan dan tanggung jawab diri, i) menyadari akanadanya beberapa pilihan dan dapat menentukan pilihan, j) dapat membuatperencanaan khusus yang berhubungan dengan perubahan tingkah laku yang akan dicapai, k) mempunyai ketrampilan sosial yang efktif, l)

14 Tatik Romlah. Teori dan Praktik Bimbingan Kelompok, (Jakarta: Dirjen Dikti, 1989), h. 14

15 Dewa Ketut Sukardi. Pengantar Pelaksanaan Program Bimbingan Kelompok di Sekolah, (Jakarta: Rineka Cipta, 2003), h. 48 
belajaruntuk lebih jujur, dan memperhatikan orang lain, 2) dapat mengklasifikasikan nilai-nilai yang ada dan memodifikasi untuk dirisendiri. ${ }^{16}$

\section{Bimbingan Kelompok dalam Menghadapi Stres}

Berdasarkan pendapat para ahli di atas layanan bimbingan kelompok merupakan salah satu media yang berorientasi kepada usaha untuk membantu individu dapat mengembangkan diri dalam rangka lebih mandiri dapat bersosialisasi dengan baik, dapat melatih berbicara, menanggapi, memberi menerima pendapat orang lain, mampu bekerja sama, peduli dengan orang lain, membina sikap dan perilaku yang normatif serta aspekaspek lainnya, tenggang rasa dan pada gilirannya individu dapat mengembangkan potensi diri serta dapat meningkatkan perilaku komunikasi pribadi yang dimilikinya, dan yang terpenting adalah belajar mengambil keputusan yang tepat untuk diri sendiri demi mencapai tujuan masa depan yang lebih baik.

Dalam layanan bimbingan kelompok dengan mempertimbangkan sumber topik yang dibahas, ada dua jenis kelompok, yaitu kelompok tugas dan kelompok bebas. Dalam "kelompok tugas", arah dan isi kegiatan kelompok atau topik bahasan ditetapkan terlebih dahulu oleh pemimpin kelompok (disingkat PK).Dalam hal ini, kelompok diberi tugas (oleh PK) untuk membahas suatu topik.Sedangkan "kelompok bebas", anggota kelompok mengemukakan atau mengusulkan topik yang dibahas dalam kelompok. Perkembangan pembahasan topik yang akan muncul dan dibahas kelompok itu sendiri nantinya yang akan menjadi isi dan mewarnai kelompok itu lebih lanjut. ${ }^{17}$

Layanan bimbingan kelompok itu mempunyai tiga fungsi Pertama, fungsi informatif, Kedua, fungsi pengembangan. Kedua fungsi ini contohnya, bimbingan kelompok yang dilaksnakan melalui kegitan Home Room , sedang Ketiga, fungsi preventif dan kreatif, digunakan untuk keperluan terapi masalah-masalah psikologi seperti psikodrama, atau sosiodrama untuk keperluan

16 Corey. Theory \& Practice of Group Counseling, (USA: Thomson Brooks, 2008), h. 5

17 Prayitno. Seri Kegiatan Pendukung Konseling, Layanan Bimbingan Kelompok/ Konseling Kelompok (L6, L7), (Padang: BK FIP UNP, 2004), h. 
terapi masalah atau konflik sosial. ${ }^{18}$ Tahap-tahap yang digunakan dalam bimbingan kelompok memiliki keragaman. Mengklasifikasikan proses bimbingan ke dalam lima tahap, yaitu tahap (a) pembentukan, (b) identifikasi, (c) produktivitas, (d) realisasi, dan (e) tahap pengakhiran. ${ }^{19}$

Menurut Corey lebih memfokuskan pada tahapan proses konseling kelompok kepada empat tahap, yaitu tahap (a) orientasi, (b) transisi, (c) kegiatan, dan (d) konsolidasi. ${ }^{20}$ Menurut Prayitno ada lima tahap dalam kegiatan bimbingan kelompok, yaitu tahap (a) pembentukan, (b) peralihan,(c) kegiatan, (d) penyimpulan, dan (e) penutup. ${ }^{21}$ Mungin Eddy Wibowo menggunakan empat tahap konseling kelompok, yaitu tahap (a) permulaan, (b) transisi, (c) kegiatan, dan pengakhiran. ${ }^{22}$ Sedangkan Gladding lebih fokus pada konseling kelompok membagi empat tahap, yaitu (a) tahap permulaan, (b) tahap transisi, (c) tahap bekerja dalam kelompok, dan (d) tahap terminasi yang merupakan suatu kesatuan dalam konseling kelompok. ${ }^{23}$ Pentahapan bimbingan kelompok yang dikemukakan para ahli memperlihatkan adanya perbedaan, namun juga terdapat kesamaan yang menggambarkan dalam tahapan bimbingankelompok terdapat proses dinamis yang menuju pada tujuan kelompok, melalui kerjasama dalam pengembangan diri dan pembahasan topik-topik secara luas dan mendalam yang bermanfaat bagi para anggota untuk mengembangkan perilaku tertentu yang lebih tepat.

Istilah stres pertama kali digunakan pada akhir abad ke-17 oleh Hook dalam konteks ilmu fisika. Namun, hingga awal abad ke-19 kata ini belum digunakan secara sistematis. Istilah stres

18 Dewa Ketut Sukardi. Manajemen Penelitian, (Jakarta: Rineka Cipta, 2000), h. 48

19 Gibson \& Mitchell. Layanan Bimbingan dan Kelompok, (Jakarta: Ghalia Indonesia. 1995), h. 199

20 Corey. Theoryand Practice of Group Counseling, (California: Monterey Brooks, 1985), h. 65

21 Prayitno. Seri Panduan Layanan dan Kegiatan Pendukung Konseling, (Padang: BK FIP UNP, 2012), h. 40-60

22 Mungin Eddy Wibowo. Konseling Kelompok, ( Unnes Press: Semarang, 2005), h. 86

${ }^{23}$ Gladding, T.S. A Counseling Specialty, (New Jersey: Pretice Hall, 1995), h. 
digunakan untuk menunjukkan kekuatan (force), tekanan (presure), ketegangan (strain), atau usaha keras (strong effor), yang ditunjukkan pada benda-benda atau manusia. Secara etimologi, istilah "stres" berasal dari bahasa latin, "stringere" yang secara harfiah berarti "keras" (strictus). Istilah ini kemudian berkembang menjadi stres, stresce, strest, dan streise. Seperti halnya dengan kebanyakan istilah-istilah lain, istilah stres telah digunakan jauh sebelum penggunaanya secara ilmiah dan sistematis. Dengan ini, istilah stres telah digunakan sejak abad ke-14 untuk menunjuk pada pengertian "kesukaran" (hardship), "kesulitan" (strait), "kesengsaraan" atau "penderitaan" (adversity), dan "kemalangan" (affliction) (Lumsden, 1981).

Stres adalah respon non-fisik (psikolgis) dari tubuh terhadap sejumlah tuntutan yang diajuk(psychological) response $f$ body to any demands made upon it) (Selye, 1980). Pengertian stres menunjukkan variasi antara ahli yang satu dengan ahli yang lainnya. Folkman dan Lazarus (dalam Chaeruni, 1995) mendefinisikan stres sebagai suatu akibat dari interaksi antara seseorang dengan lingkungannya yang dinilai membahayakan dirinya. Gibson (dalam Chaeruni, 1995) mendefinisikan stres sebagai interaksi antara stimulus dan respon.

Stres sebagai stimulus adalah kekuatan atau dorongan terhadap individu yang menimbulkan reaksi ketegangan atau menimbulkan perubahan-perubahan fisik individu. Stres sebagai respon yaitu respon individu baik respon yang bersifat fisiologis maupun respon yang bersifat psikologis, terhadap stressor yang berasal dari lingkungan. Stressor tersebut merupakan peristiwa atau situasi dari luar yang bersifat mengancam individuan padanya (Stress is the non-speci) Stres adalah perasaan tertekan, perasaan tertekan ini membuat orang mudah tersinggung, mudah marah, konsentrasi terhadap pekerjaan menjadi terganggu. Stres merupakan reaksi tubuh terhadap situasi yang tampak berbahaya atau sulit. Stres membuat tubuh untuk memproduksi hormon adrenalin yang berfungsi untuk mempertahankan diri.

Stres merupakan bagian dari kehidupan manusia. Stres yang ringan berguna dan dapat memacu seseorang untuk berpikir dan berusaha lebih berpikir dan berusaha lebih cepat dan keras sehingga dapat menjawab tantangan hidup sehari-hari. 
Stres ringan bisa merangsang dan memberikan rasa lebih bergairah dalam kehidupan yang biasanya membosankan dan rutin. Tetapi stres yang terlalu banyak dan berkelanjutan, bila tidak ditanggulangi akan berbahaya bagi kesehatan. Beranjak dari beberapa definisi ahli dapat disimpulkan bahwa stres merupakan respon spesifik dari organisme terhadap stressor yang dapat berakibat negatif maupun positif. Bila organisme tidak kuat menghadapi dan menganggap stressor tersebut sebagai tuntutan dari lingkungan yang menekan, maka stressor dapat menyebabkan ketegangan yang selanjutnya dapat mengakibatkan gangguan pada fisik dan psikisnya. Namun, bila individu tersebut mampu menghadapi dan mengelola stressor dengan baik, maka akan timbul hal-hal yang positif.

\section{a. Sumber Stres}

Stres merupakan fenomena yang tidak bisa dipisahkan dari kehidupan manusia. Semua manusia, baik anak-anak, remaja ataupun orang tua mengalami stres. Sumber stres dapat berubahubah sejalan dengan perkembangan manusia, tatapi kondisi stres dapat terjadi pada setiap saat sepanjang kehidupan.

Dalam kajian psikologi tentang stres, dikenal istilah stressor dan demands yang sering digunakan untuk menyebut sumber stres (sources of stres). Menurut Quick stressor adalah respon individual terhadap stimulus fisiologis dan psikologis. Ini berarti bahwa stres dapat bersumber dari dalam dan luar diri individu. Hal ini sejalan dengan pendapat Lazarus yang mengatakan bahwa sumber stres secara garis besarnya dapat dibedakan atas dua jenis, yaitu tuntutan dari dalam diri (internal demands) dan tuntutan dari luar diri (lingkungan) (eksternal demands). ${ }^{24}$

Tuntutan internal yang menjadi sumber stres ini antara lain meliputi: kemampuan, harapan, ambisi, motivasi, karakteristik kepribadian, kemampuan diri, harga diri dan sebagainya. Sedangkan tuntutan eksternal bersifat sangat kompleks dan bervariasi, meliputi elemen-elemen di lingkungan luar, seperti keluarga, teman, dan pekerjaan.

24 Lazarus, R.S., \&Launier, R. Stres yang berhubungan dengan transaksi antara orang dan lingkungan, dalam: Pervin, L.A and lewis, M., Persfektives in interactional psychology, (New York: Plenum Press, 1978) 
Sarafino membedakan sumber-sumber stres atas tiga bentuk yaitu: 25

a. Sumber stres dalam diri individu, seperti melalui kesakitan (illness).

b. Sumber stres di dalam keluarga, seperti perselisihan dalam masalah keuangan, perasaan saling acuh tak acuh, tujuantujuan yang saling berbeda, dan sebagainya.

c. Sumber stres dalam komunitas dan lingkungan, seperti pengalaman stres remaja di sekolah atau pengalaman stres orang tua yang bersumber dari pekerjaan. Ahli yang lain mengemukakan tentang sumber-sumber stres adalah Martin dan Osbome. Dalam hal ini Martin dan Osbome (1989), membedakan sumber stres atas tiga jenis yaitu: Eviromental stressor, yaitu sumber stres yang berhubungan dengan perubahan-perubahan besar yang terjadi dalam kehidupan keseharian seperti; perkawinan, kematian pasangan, perceraian, perpindahan sekolah, memasuki usia puberitas, yang disertai dengan perubahan biologis dan sosial, pensiun dari pekerjaan, dan sebagainya. Psychological stressor, yaitu yang dikaitkan dengan aspek-aspek kepribadian individu. Seseorang dengan kepribadian kompetitif yang berlebihan, kemauan keras, tidak sabar, mudah marah, dan agresif, lebih mudah terserang penyakit jantung kroner. Physical stressor, yaitu sumber stres yang berhubungan dengan keadaan tubuh yang tidak benar, minum alkohol secara berlebihan, dan sebagainya.

Di samping stressor yang disebutkan di atas, pendekatan yang tergolong baru lebih memberikan perhatian pada kejadiankejadian traumatis yang ekstrim, baik buatan manusia (seperti perang) maupun bencana alam (seperti tsunami, ternado) sebagai sumber stres.

\section{b. Dampak Stres}

Stres adalah suatu kondisi anda yang dinamis saat seorang individu dihadapkan pada peluang, tuntutan, atau sumber daya yang terkait dengan apa yang dihasratkan oleh individu itu dan yang hasilnya dipandang tidak pasti dan penting. Stres adalah

25Sarafino, Edward. P. Kesehatan psikologi: interaksi Bioppsychologycal, (New York: jhonWeley \& Sons, 1990) 
beban rohani yang melebihi kemampuan maksimum rohani itu sendiri, sehingga perbuatan kurang terkontrol secara sehat.

Stres tidak selalu buruk, walaupun biasanya dibahas dalam konteks negatif, karena stres memiliki nilai positif ketika menjadi peluang saat menawarkan potensi hasil. Sebagai contoh, banyak profesional memandang tekanan berupa beban kerja yang berat dan tenggang waktu yang sempit sebagai tantangan positif yang menaikkan mutu pekerjaan mereka dan kepuasan yang mereka dapatkan dari pekerjaan mereka.

Stres bisa positif dan bisa negatif. Para peneliti berpendapat bahwa stres tantangan, atau stres yang menyertai tantangan di lingkungan kerja, beroperasi sangat berbeda dari stres hambatan, atau stres yang menghalangi dalam mencapai tujuan.Meskipun riset mengenai stres tantangan dan stres hambatan baru tahap permulaan, bukti awal menunjukkan bahwa stres tantangan memiliki banyak implikasi yang lebih sedikit negatifnya dibanding stres hambatan.

Sesuai dengan konsep stres yang diajukan oleh Lazarus, reaksi terhadap stres sangat tergantung pada individu menginterprestasikan atau menilai (secara sadar atau tidak) arti dari peristiwa yang mengancam atau menantang baginya. Sejauh mana kemampuan individu untuk mengatasi ancaman yang dihadapinya, sangat menentukan intensitas penghayatannya terhadap stres. Ini berarti bahwa stres psikologis memiliki makna yang berbeda-beda pada setiap individu. Karena perbedaan dalam memaknai situasi stres ini, maka reaksi yang muncul dari setiap individu untuk menanggulangi stres juga berbeda-beda. Lazarus juga menyebut reaksi individu untuk menanggulangi stres ini dengan istilah "coping strategy". Dewasa ini telah menjadi pedoman untuk memahami reaksi stres, sehingga tidak berlebihan kalu dikatakan "the way people cope with stress my be even more important tooverall morale, sosial functioning and health/illness than the frequency and severity of episodes of stres themselves...." Rutter (1999).

Ada dua proses penting yang perlu bagi individu dan lingkungannya, yaitu cognitive appraisal (penilaian kognitif) dan coping strategy (strategi penanggulangannya). Karena adanya keduanya proses ini, maka stres akan bermakna positif ataupun 
negatif sangat tergantung pada individu yang mengalaminya. ${ }^{26}$ Stres bahkan bermakna negatif, apabila individu menghayati situasi yang dihadapinya sebagai ancaman, atau ia merasakan adanya hambatan atau keterbatasan dalam diri untuk menghadapi tuntutan situasi tersebut. Sebaliknya, apabila individu menilai suatu yang dihadapinya sebagai tantangan untuk berusaha melakukan sesuatu, maka stres akan bermakna positif, karena situasi tersebut tidak sampai mengganggu dirinya.

Penilaian kognitif dapat dipahami sebagai proses mental yang berlangsung secara terus menerus untuk menginterprestasikan sebagai situasi dalam interaksinya dengan individu. Penilaian kognitif ini terjadi melaui dua tahap penilaian, yaitu primary appraisal (serangkaian penilaian yang berkaitan dengan keberadaan individu di dalam lingkungannya), dan scondary appraisal (proses evaluasi yang lebih kompleks, termasuk pilihan yang akan memberi arah pada proses penanggulangan atau coping yang dilakukan individu). Kedua bentuk penilaian kognitif ini saling mempengaruhi dan akan mencerminkan keunikan antara individu yang satu dengan individu yang lain melalui beberapa karakteristik, seperti sistem nilai, persepsi, dan proses berfikir Elmira (1993).

Dengan demikian dapat dipahami bahwa tinggi atau rendahnya derajat stres yang dinilai oleh individu merupakan relasi integratif faktor personal dan eksternal dari individu yang tercakup dalam suatu penilaian kognitif. Penilaian kognitif ini selanjutnya akan berpengaruh terhadap pola penanggulangannya (coping) yang digunakan oleh individu yang bersangkutan dalam mengatasi stres tersebut.

\section{Kesimpulan}

Stres sebagai stimulus adalah kekuatan atau dorongan terhadap individu yang menimbulkan reaksi ketegangan atau menimbulkan perubahan-perubahan fisik individu. Stres sebagai respon yaitu respon individu baik respon yang bersifat fisiologis maupun respon yang bersifat psikologis, terhadap stressor yang berasal dari lingkungan. Stressor tersebut merupakan peristiwa

26 Lazarus, R.S., \&Folkman, S., Stres, Appraisal dan Copping, (NewYork: McGraw-Hill, 1984) 
atau situasi dari luar yang bersifat mengancam individuan padanya (Stress is the non-speci) Stres adalah perasaan tertekan, perasaan tertekan ini membuat orang mudah tersinggung, mudah marah, konsentrasi terhadap pekerjaan menjadi terganggu. Stres merupakan reaksi tubuh terhadap situasi yang tampak berbahaya atau sulit. Stres membuat tubuh untuk memproduksi hormon adrenalin yang berfungsi untuk mempertahankan diri.

Bimbingan kelompok merupakan salah satu teknik bimbingan yang berusaha membantu individu agar dapat mencapai perkembangan secara optimal sesuai dengan kemampuan bakat, minat, serta nilai-nilai yang dianutnya dan dilaksanakan dalam situasi kelompok.Bimbingan kelompok ditujukan untuk mencegah timbulnya masalah pada individu dan mengembangkan potensi individu. Layanan bimbingan kelompok itu mempunyai tiga fungsi Pertama, fungsi informatif, Kedua, fungsi pengembangan. Kedua fungsi ini contohnya, bimbingan kelompok yang dilaksnakan melalui kegitan Home Room, sedang Ketiga, fungsi preventif dan kreatif, digunakan untuk keperluan terapi masalah-masalah psikologi seperti psikodrama, atau sosiodrama untuk keperluan terapi masalah atau konflik social.

Dalam tulisan ini layanan bimbingan kelompok merupakan salah satu media yang berorientasi kepada usaha untuk membantu individu dapat mengembangkan diri dalam rangka lebih mandiri dapat bersosialisasi dengan baik, dapat melatih berbicara, menanggapi, memberi menerima pendapat orang lain, mampu bekerja sama, peduli dengan orang lain, membina sikap dan perilaku yang normatif serta aspek-aspek lainnya, tenggang rasa dan pada gilirannya individu dapat mengembangkan potensi diri serta dapat meningkatkan perilaku komunikasi pribadi yang dimilikinya, dan yang terpenting adalah belajar mengambil keputusan yang tepat untuk diri sendiri demi mencapai tujuan masa depan yang lebih baik. 


\section{Daftar Pustaka}

Corey. Theory \& Practice of Group Counseling, (USA: Thomson Brooks, 2008)

Dewa Ketut Sukardi. Pengantar Pelaksanaan Program Bimbingan Kelompok diSekolah. (Jakarta: Rineka Cipta, 2003)

Elizabeth B. Hurlock. Psikologi Perkembangan Suatu Pendekatan Kehidupan, (Erlangga, 1997)

Erman Amti, Prayitno. Seri Kegiatan Pendukung Konseling, Layanan Bimbingan Kelompok/ Konseling Kelompok, (Padang: BK FIP UNP, 2004)

Gibson \& Mitchell. Layanan Bimbingan dan Kelompok, (Jakarta: Ghalia Indonesia. 1995)

Gladding, T.S. A Counseling Specialty, (New Jersey: Pretice Hall, 1995)

Juntika. Dasar-dasardanTeknikEvaluasiPendidikan, (Padang: UNP, 2005)

Lazarus, R.S., \&Folkman, S., Stres, Appraisal dan Copping, (NewYork: McGraw-Hill, 1984)

Lazarus, R.S., \&Launier, R. Stres yang berhubungan dengan transaksi antara orang dan lingkungan, dalam: Pervin, L.A and lewis, M., Persfektives in interactional psychology, (New York: Plenum Press, 1978)

Mungin Eddy Wibowo. Konseling Kelompok, (Unnes Press: Semarang, 2005)

Prayitno. Seri Bimbingan dan Konseling di sekolah (Dasar dan Profil), (Jakarta : Ghalia Indonesia

Sarafino, Edward. P. Kesehatan psikologi: interaksi Bioppsychologycal, (New York: jhonWeley \& Sons, 1990)

Syamsu Yusuf. Seri Kegiatan Pendukung Konseling, Layanan Bimbingan Kelompok/ Konseling Kelompok, (Padang: BK FIP UNP, 2004)

Tatik Romlah, Teori dan Praktik Bimbingan Kelompok, (Jakarta: Dirjen Dikti, 1989)

Tatik Romlah. Teori dan Praktik Bimbingan Kelompok, (Jakarta: Dirjen Dikti, 1989) 